\title{
Effect of Abiotic Factors on Population Dynamics of Whitefly and Jassid on Bt Cotton
}

\author{
Muhammad Zuhaib Safdar*, Muhammad Naeem, Muhammad Mamoon ur Rashid and Umar Niaz \\ Department of Entomology, University of Agriculture, Faisalabad, Pakistan
}

*Corresponding author: Muhammad Zuhaib Safdar, Department of Entomology, University of Agriculture, Faisalabad, Pakistan

\begin{abstract}
Studies was carried out to investigate population dynamics and the effect of abiotic factors on population dynamics of sucking insect pests of BT cotton whitefly (Bemisia tabaci) and jassid (Amrasca biguttula), under unprotected condition. The results of the field study revealed that the sucking pest (whiteflies and jassids) population were maximum at highest temperature. (11.68) of whiteflies per leaf was recorded at highest temperature (45 oC) and lowest humidity $(30 \%)$. Similarly, the maximum population (3.53) of jassids per leaf was recorded at maximum temperature (45 oC) and lowest humidity (30\%) on July 10th, 2017. The rainfall had slight impact on the population of whiteflies and Jassids. Simple correlation analysis revealed that maximum temperature showed significant positive effect and the minimum temperature showed negative effect on these pests. The relative humidity was non-significant effect, whereas precipitation was negative effect on all the sucking pests
\end{abstract}

Keywords: Minimum Temperature; Lowest Humidity; Economy of Pakistan; Different Pest Control Tactics; Plant Viruses; Black Sooty Mold Grows Ripening of Bolls

\section{Introduction}

WCotton (Gossypium hirsutum L.) contributes much to the economy of Pakistan [1]. It supports our textile industries. Cotton being a natural fiber crop is also called silver-fiber for its unique quality [2]. Cotton uses are ranging from garments to furnishings of homes and medicines. Pakistan stands $5^{\text {th }}$ biggest producer and $4^{\text {th }}$ major cotton user throughout the world and the major exporter of cotton yarn (APTMA, 2015). Cotton is cultivated over 3 million hectares in Pakistan and its share in GDP is $1.5 \%$. It contributes $7.0 \%$ in value added to agriculture [3]. Among a variety of reasons of low yield, the magnitude of insect-pests, which damage the cotton crop from sowing to maturity, plays an important role. The insectpests cause $5-10 \%$ losses on an average but in severe attack, insectpests can cause heavy qualitative and quantitative losses varying from $40-50 \%$ [4]. There are different pest control tactics, in which varietal resistance is immense without insecticide application $[5,6]$.

Cotton insect pest complex is divided into two categories; sucking insect pests and chewing insect pests. Important sucking insect pests are whitefly (Bemisia tabaci), jassid (Amrasca biguttula), thrips (Thrips tabaci) and aphid (Aphis gossypii) which are also designated as key pests causing most of the damage to cotton crop. Cotton whitefly damages the plant by sucking cell sap resulting in 50\% reduction in boll production [7] and act as a vector of leaf curl virus disease (CLCV) [8], which is threatening our cotton-based economy. It acts as a sole vector of more than 100 plant viruses, which cause diseases to many commercial crops in different parts of the world [9]. Heavy infestation may reduce plant vigor and growth, cause chlorosis and uneven ripening of bolls. Its direct feeding induces physiological disorders resulting in shedding of immature fruiting parts. Its nymphs produce honeydew, on which black sooty mold grows, reducing the photosynthetic capabilities of plants. Similarly, jassid is also a notorious sucking insect pest of cotton plant [10]. Whitefly and jassid populations are usually positively correlated with the temperature while negative with relative humidity. In discriminate use of insecticides has not only caused the resistance problem in these pests but also has polluted the environment along with other health hazards [10,11]. Understanding the host selection behavior and the effect of various morphological plant characters is an important prerequisite for developing the pest management strategy.

Cotton Jassid, Amrasca biguttula is one of the most serious sucking pests of cotton in India causing reduction in yield to an extent of 20 percent. Nymphs and adults suck sap from the under surface of the leaves and causing downward curling, yellowing and reddening of leaf lamina which results later in hopper burn and in severe cases leaves dry and drop down. A good cotton crop with minimal 
pest attack brings prosperity, while severe incidence brings misery. Thus, pest is an important determinant of the prosperity of the farmers. The knowledge about incidence of pest during the cropping season and its possible dynamics help in designing pest management strategies.

\section{Objective}

Keeping in view the present studies were carried out to study population dynamics of whitefly and jassid on cultivar of cotton MNH-886 (Bt-cultivar) in agro climatic conditions of Dera Ismail Khan, Pakistan.

\section{Materials and Methods}

A field study was carried out during the months of July and August (2017) at Department of Entomology, Faculty of Agriculture, Gomal University, Dera Ismail Khan, Pakistan. The cotton Bt-variety MNH-886 was grown in the observation plot with recommended agronomic package of practices. Observations on the number of nymphs and adults of ehiteflies and jassids were recorded 9 times on weekly basis from three leaves per plant selected from top, middle and bottom on 30 randomly selected plants (Table
1). Weather data (temperature, relative humidity, wind speed and rainfall) of concerned dates was obtained and compared with the fluctuating population of jassids and whiteflies.

Table 1: Economic threshold levels of different insect pests of cotton crop.

\begin{tabular}{|c|c|}
\hline Insect Pests & Economic Threshold Level \\
\hline Jassid & 1 adult/nymph per leaf \\
\hline Whitefly & 5 adult/nymph per leaf \\
\hline Thrips & 8-10 per leaf \\
\hline Aphid & $10 /$ leaf or on visible damage \\
\hline Mite & $15 /$ leaf or on visible damage \\
\hline American boll worm & $\begin{array}{l}5 \text { brown eggs or } 3 \text { larvae/ } \\
\text { plant }\end{array}$ \\
\hline Spotted bollworm & 3 larvae/plant \\
\hline Pink bollworm & $\begin{array}{l}5 \% \text { damage or presence of } \\
\text { larvae in boll }\end{array}$ \\
\hline Army bollworm & Just at appearance \\
\hline
\end{tabular}

\section{Result and Discussion}

Table 2: Population dynamics of whiteflies and jassids on cotton crop in agro-climatic conditions of Dera Ismail Khan during 20172018.

\begin{tabular}{|c|c|c|c|c|c|c|c|c|c|}
\hline \multirow{2}{*}{$\begin{array}{c}\text { Observation } \\
\text { Dates }\end{array}$} & \multirow{2}{*}{ Weeks } & \multirow{2}{*}{ W. flies/leaf } & \multirow{2}{*}{ Jassids/leaf } & \multicolumn{2}{|c|}{ Temperature $\left({ }^{\circ} \mathrm{C}\right)$} & \multicolumn{2}{|c|}{ R. humidity (\%) } & \multirow{2}{*}{$\begin{array}{c}\text { Wind speed } \\
\qquad \mathrm{Km} / \mathrm{hr}\end{array}$} & \multirow{2}{*}{$\begin{array}{r}\text { Rainfal } \\
(\mathrm{mm})\end{array}$} \\
\hline & & & & Max & Min & Max & Min & & \\
\hline 3-Jul & 1 & 10.9 & 3.5 & 42 & 26 & 34 & 27 & 4.08 & - \\
\hline 10-Jul & 2 & 11.68 & 3.53 & 45 & 24 & 30 & 27 & 3.25 & - \\
\hline 16-Jul & - & - & - & - & - & - & - & - & 34 \\
\hline 17-Jul & 3 & 6.94 & 3.25 & 38 & 22 & 39 & 32 & 2.75 & - \\
\hline 24-Jul & 4 & 10.73 & 3.44 & 40 & 24 & 40 & 27 & 2.66 & - \\
\hline 25-Jul & - & - & - & - & - & - & - & - & 16 \\
\hline 31-Jul & 5 & 10.71 & 3.46 & 40 & 22 & 40 & 32 & 2.5 & - \\
\hline 7-Aug & 6 & 10.4 & 3.42 & 40 & 25 & 58 & 141 & 2.42 & - \\
\hline 14-Aug & 7 & 10.1 & 3.4 & 36 & 25 & 46 & 41 & 3.12 & - \\
\hline 21-Aug & 8 & 9.85 & 3.22 & 32 & 22 & 44 & 30 & 1.88 & - \\
\hline 26-Aug & - & - & - & - & - & - & - & - & 80 \\
\hline 28-Aug & 9 & 8.74 & 3.12 & 34 & 22 & 50 & 40 & 2.84 & - \\
\hline
\end{tabular}

The data presented in Table 2 show that the increasing temperature positively affected the population of whiteflies and jassids on cotton. The maximum population (11.68) of whiteflies was recorded at highest temperature ( $45 \mathrm{oC})$ and lowest humidity (30\%) (Figure 1). Similar trend of jassid population build up was recorded. The maximum population (3.53) of jassids was recorded at maximum temperature (45 oC) and lowest humidity (30\%) on July $10^{\text {th }}, 2017$. The rainfall had slight impact on the population of whiteflies and Jassids. In case of no rainfall, favourable environmental conditions like high temperature and low humidity were found for the population build-up of whiteflies and jassids.
Similar results have been reported by different scientists Gogoi et al. [12]; Murugan and Uthamasamy [13] and Panicker and patel [14] reported that meteorological parameters play an important role in the population fluctuation of sucking insect pests (Figure 2). The present findings are in agreement with the findings of Umar et al. (2003) and Bishnol et al. (1996) who reported that jassid population increased with maximum temperature. Shivam et al. (2011) documented that maximum temperature showed significant positive effect on all the sucking pests. The minimum temperature showed negative effect on population of whitefly and jassid. 


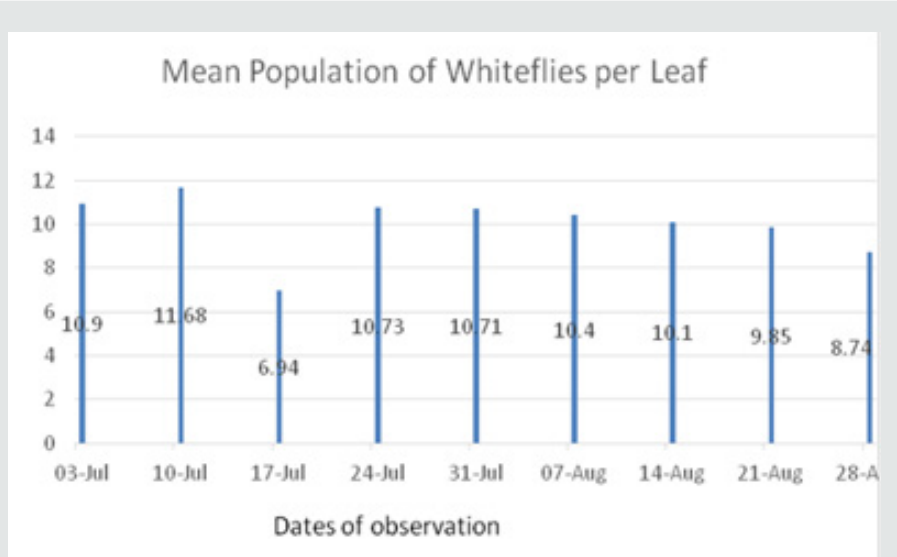

Figure 1: Population dynamics of whiteflies on cotton crop in agro-climatic conditions of Dera Ismail Khan during $2017-2018$.

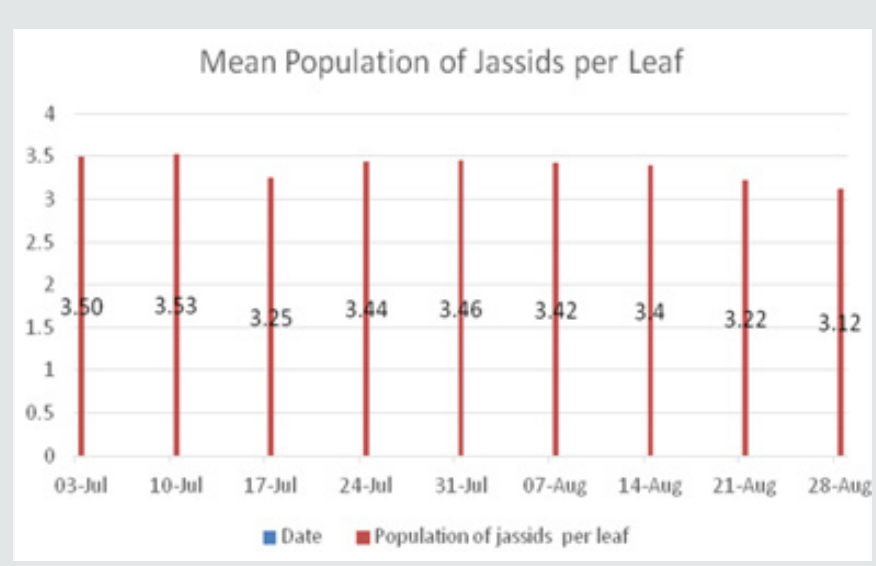

Figure 2: Population dynamics of jassids on cotton crop in agro-climatic conditions of Dera Ismail Khan during 2017-2018.

\section{Conclusion}

On the basis of obtained results it is concluded that the increasing temperature positively affected the population of whiteflies and jassids whereas relative humidity and rainfall negatively affected the population of the tested insects. The abiotic factors did not play significant role in mediating population dynamics of these pests.

\section{References}

1. Ibrahim M, J Akhtar, M Younis, MA Riaz, M Anwar ul Haq (2007) Selection of cotton (Gossypium hirsutum L.) genotypes against $\mathrm{NaCl}$ stress. Soil and Environ 26: 59-63.

2. Arshad M, M Anwar (2007) Best methods/practices to increase per acre cotton yield. Ministry of Textile Industry, Pakistan. APTMA. World Cotton and non-Cotton Fiber Consumption.

3. Annonymous (2015) Economic Survey of Pakistan, Ministry of Food, Agric. and Livestock Division (Economic Wing), Islamabad, Pakistan.

4. Naqvi KM (1976) Crop protection to boost up cotton production. Proc. Cotton. Prod. Seminar, Organized by ESSO Fert. Co. Ltd., Pakistan, pp. 119-125.

5. Bughio AR, A Rahman, AQ Zafar, T Hussain, QH Siddiqui (1984) Field evaluation of cotton mutants for pink and spotted bollworms resistance. The Nucleus Pakistan 21: 47-49.

6. Khan MT, M Naeem, M Akram (2003) Studies on the varietal resistance of cotton against insect pest complex of cotton. Sarhad J Agri 19: 93-96.
7. Ahmad M, MI Arif, Z Ahmad, I Denholm (2002) Cotton whitefly (Bemisia tabaci) resistance to organophosphate and pyrethroid insecticides in Pakistan. Pest Manag Sci 58(2): 203-208.

8. Nelson MR, A Nadeem, W Ahmad, TV Orum (1998) Global assessment of cotton viral diseases. Proc. Beltwide cotton Conf., San Diego, CA. Natl cotton counc Am pp. 161-162.

9. Jones DR (2003) Plant viruses transmitted by whiteflies. European J Plant Pathol 109(3): 195-219.

10. Bashir MH, M Afzal, MA Sabri, AM Raza (2001) Relationship between sucking pests and physio-morphic plant characters towards resistance/ susceptibility in some new cotton genotypes of cotton. Pak Entomol 23: 75-78.

11. Raza AM, Afzal (2000) Physico-morphic plant characters in relation to resistance against sucking insect pests in some new cotton genotypes. Pak Entom 22: 73-78.

12. Gogoi I, Dutta BC, Gogoi (2000) Seasonal abundance of cotton jassid on okra. J Agric Sci Society 13: 22-26.

13. Murugan M, Uthamasamy S (2001) Dispersal behaviour of cotton whitefly, Bemisia tabaci under cotton based garden land agro ecosystem of Coimbatore. Madras Agric J 88: 1-6.

14. Panickar BK, Patel JB (2001) Population dynamics of different species of thrips on chilli, cotton and pigeon pea. Indian J Entomol 63: 170-175. 
(c) This work is licensed under Creative

To Submit Your Article Click Here: Submit Article

DOI: $10.32474 / C I A C R .2019 .06 .000226$

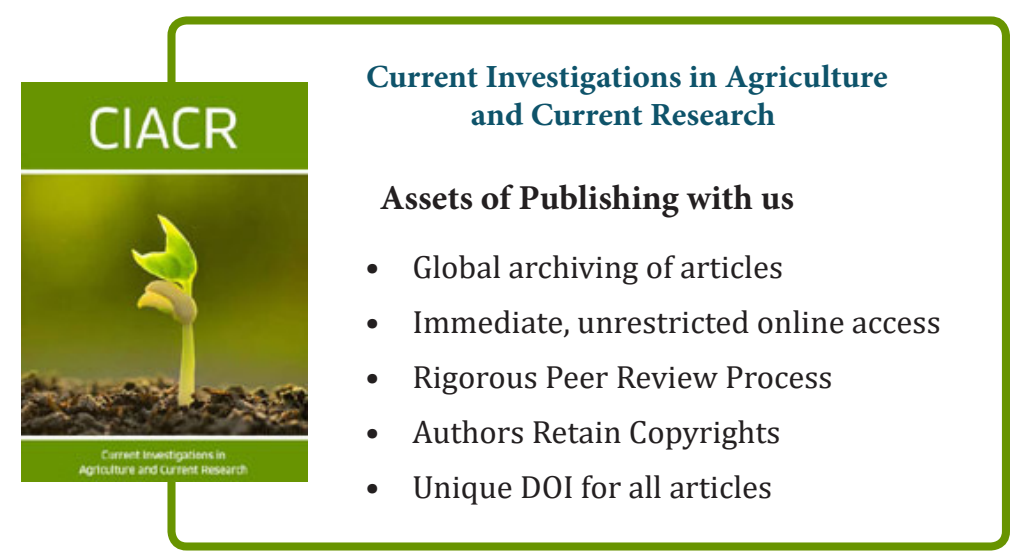

